DOI: https://doi.org/10.31392/NZ-npu-145.2019.18

УДК 378.147:811.111

Ратушняк Н. 0.

\title{
ІНДИВІДУАЛІЗАЦІЯ ІНКЛЮЗИВНОГО НАВЧАННЯ УЧНІВ ПОЧАТКОВОЇ ШКОЛИ В СИСТЕМІ ПІДГОТОВКИ МАЙБУТНІХ ВЧИТЕЛІВ
}

У статті висвітлено проблему підготовки майбутніх вчителів початкової школи до організації індивідуалізаиії в інклюзивних класах. Проаналізовано наукові праці зарубіжних $i$ вітчизняних дослідників циієі проблеми. Виокремлено найбільш суттєві ознаки, які характеризують індивідуальний підхід. Подано структуру прочесу індивідуалізачії, в якій сформулювало прочесуальні компоненти індивідуалізачї та їх елементи. Охарактеризовано основний принцип та складові інклюзивної освіти. Визначено найважливіші функції вчителя під час індивідуалізації інклюзивного навчання: стимулювання пізнавальної діяльності, постійний контроль за виконанням завдань; підбір спеціальних методів; прийомів та засобів для учнів з особливими потребами; своєчасна допомога у подоланні труднощів у навчанні. Виокремлено основні корекційні уміння, якими повинен володіти вчитель інклюзивного класу початкової школи. Запропоновано спеціальні вправи для розвитку учнів з особливими потребами.

Ключові слова: інклюзивна освіта, учні початкової школи, учні з особливими потребами, індивідуалізачія навчання, індивідуальний підхід, психофізичні особливості, навчальнопізнавальна діяльність.

Проблема індивідуальних особливостей учнів початкової школи 3 особливими потребами і можливості їх врахування в навчально-виховному процесі $є$ важливою і цінною для педагогічної науки. Часто громадські інтереси ставляться вище особистих, повністю поглинаючи їх і не даючи можливості прояву неповторної і унікальної індивідуальності людини. Майбутні фахівці часто не готові забезпечити індивідуалізацію інклюзивного навчання учнів початкової школи, тому у сучасному суспільстві важливою $є$ проблема їхньої підготовки саме у цьому напрямку.

Модернізація вищої школи відповідно до законів України про освіту та документів Болонської декларації передбачає посилену увагу до покращення якості освітнього процесу, центром якого $€$ розвиток профресійної компетентності вчителя початкової школи. Сучасні наукові розробки сприяють удосконаленню підготовки майбутніх учителів початкової освіти до профресійної діяльності. На сучасному етапі розвитку української держави актуальною $є$ потреба пошуку нових шляхів реалізації творчих можливостей індивідуальності, і саме вчитель здатен виявити унікальність суб'єктів освітнього процесу та створити умови для їх креативного вираження. Тому пріоритетною проблемою закладів вищої освіти педагогічного спрямування на етапі інтеграції України до європейського освітнього простору є підготовка вчителя нової генерації: сучасній школі потрібні вчителі, які здатні забезпечити реалізацію творчого потенціалу учня незалежно від його особливостей розвитку. 
Гостро постало протиріччя між традиційною системою підготовки педагогічних кадрів для інклюзивної освіти і потребами практики, що засвідчує дефіцит масових загальноосвітніх закладів освіти у спеціальних педагогічних фахівцях, здатних надати дитині з особливими освітніми потребами якісні освітні послуги в умовах інклюзивного освітньо-розвивального середовища. Недостатній рівень професійної компетентності психолого-педагогічних кадрів у галузі інклюзивного навчання свідчить про існування глибокої проблеми в сучасній професійній освіті, яку неможливо розв'язати тільки за допомогою фахівців спеціальної освіти, що підкреслює важливість підготовки та перепідготовки учителів для освітньої інклюзії.

Проблема індивідуалізації знаходить відображення в наукових працях вітчизняних і зарубіжних фрілософів, психологів i педагогів. Однак, характеризуючи поняття індивідуалізації як педагогічної проблеми, ми стикаємося 3 необхідністю виявлення дефініції цього поняття. Орієнтиром $є$ визначення, що мають місце в працях сучасних вчених і мислителів минулого. Вони стали основою для реалізації того чи іншого педагогічного підходу в напрямку індивідуалізації навчання дітей, які мають ті чи інші відхилення у фізичному чи психічному розвитку.

Вивченню цього питання приділяли належну увагу зарубіжні та вітчизняні науковці. Зокрема, серед психологічних досліджень, присвячених питанням розвитку особистості, слід назвати роботи таких науковців як Б. Ананьєв, А. Асмолова, І. Бех, І. Зимня, Є. Ільїн, М. Левітов, О. Леонтьєв, С. Рубінштейн. Проблему професійної підготовки майбутніх педагогів розглядали Г. Баллом, С. Гончаренком, М. Євтухом, І. Зязюном, Н. Кичук, В. Кременем, Н. Ничкало, О. Пєхотою, О. Савченко, В. Семиченко, С. Сисоєвою та іншими. Питання підготовки вчителя початкової школи досліджували В. Бондар, Н. Бібік, М. Вашуленко, Н. Кичук, О. Савченко.

У процесі вивчення проблеми індивідуалізації інклюзивного навчання учнів початкової школи з'являється необхідність конкретизації сутності понять, які $€$ основою для побудови категоріального апарату дослідження. 3 цією метою нами було проаналізовано педагогічні і психологічні довідники, праці вітчизняних та зарубіжних педагогів та психологів, періодичні видання з даної теми.

Це дає змогу виокремити, на нашу думку, найбільш суттєві ознаки, що характеризують індивідуальний підхід. Індивідуальний підхід розуміємо як принцип навчання і виховання, в основі якого лежить урахування індивідуально-психологічних особливостей учнів для гармонізації їх внутрішнього світу. Під індивідуально-психологічними особливостями учнів розуміються незмінні якості індивідуальності, такі як характер і темперамент, задатки і схильності, спрямованість і інтерес, які проявляються в активній навчально-пізнавальній діяльності учнів.

Організація навчальної діяльності передбачає створення комфортного освітньо-розвивального середовища навчання, пошук принципово нових і зміну існуючих фрорм і методів навчання, де перш за все будуть враховуватися індивідуальні особливості і якості учнів. 
Структуру процесу індивідуалізації можна відобразити в такій схемі (рис. 1.1).

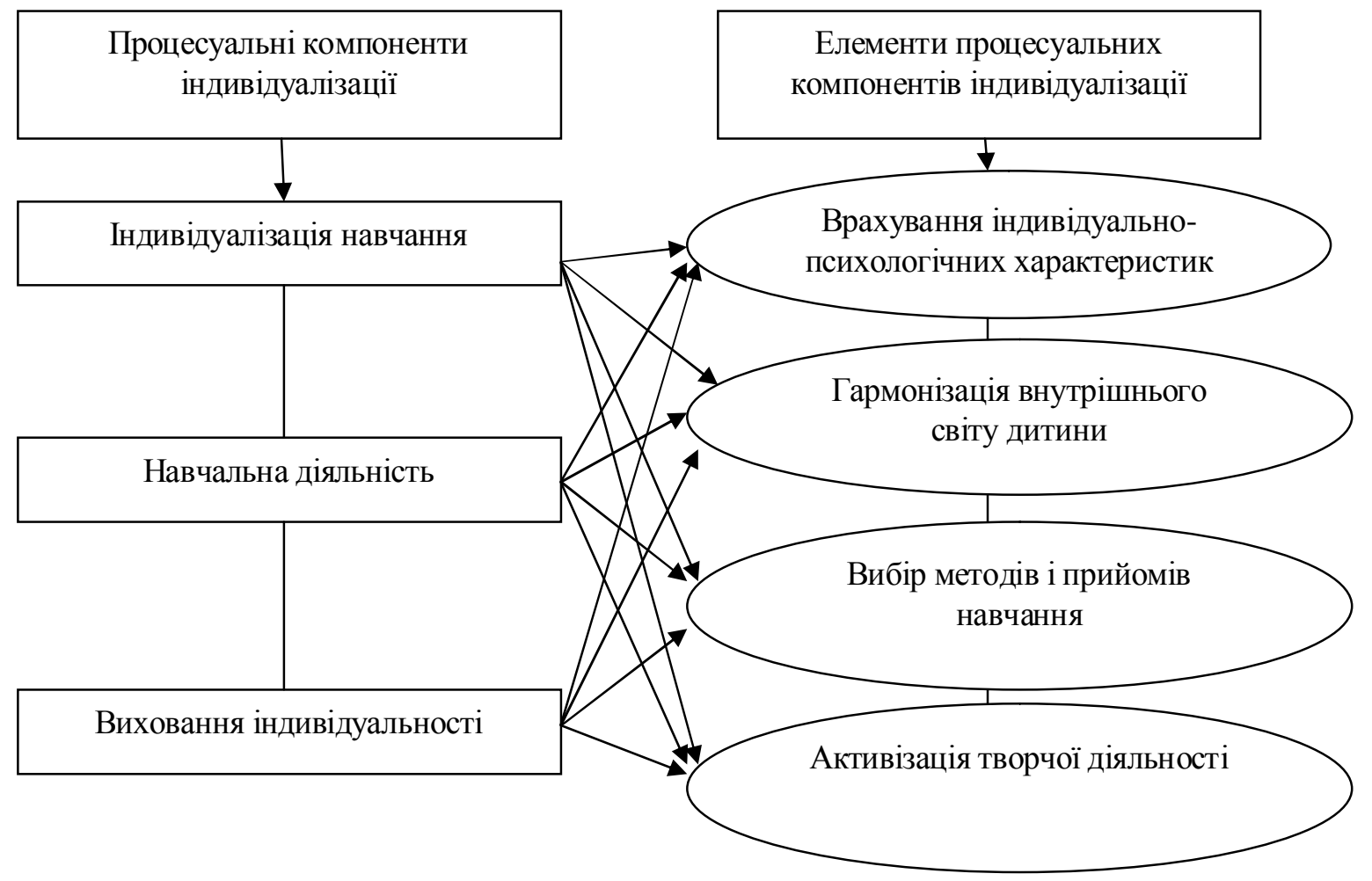

Рис. 1.1. Прочес індивідуалізації навчання і його складові

Дана схема демонструє сутність процесу індивідуалізації, а саме конкретизує процесуальні компоненти та їх елементи. Саме взаємозв'язок цих компонентів і елементів дає змогу повною мірою реалізувати індивідуальний підхід в процесі навчання учнів молодшого шкільного віку з особливими потребами.

Індивідуалізація являє собою урахування індивідуальності учнів у навчальній роботі. Індивідуальність - сукупність рис, що визначають самобутність людини, її відмінність від інших людей; своєрідність психіки та особистості індивіда, її неповторність. Вона виявляється в рисах темпераменту, характеру, у специфіці інтересів, якостей перцептивних процесів і інтелекту, потреб і здібностей індивіда. У психології індивідуальність характеризують як цілісну характеристику окремої людини, ії̈ оригінальність, самобутність психологічної структури [6].

Дослідження психологічної основи індивідуалізації навчання в загальноосвітній школі дає змогу виокремити особливості учнів, які найперше слід ураховувати в процесі індивідуалізації навчальної роботи:

- навченість (наявність певного обсягу систематизованих знань і вміння їх використовувати , система сформованих навичок);

- здатність до навчання (особливості уваги, сприймання, пам'яті, оволодіння необхідними логічними операціями, навчальними прийомами, 
гнучкість мислення);

- ставлення учнів до навчання (мотиви учіння);

- рівень самоорганізації навчання [4].

Крім психологічних чинників, на навчальний процес впливає і стан здоров'я дитини. Хвороби, залежно від їх характеру, спричиняють на учня тимчасовий або постійний негативний вплив - знижують його працездатність. Різні фрізичні дефекти (розлад зору, слуху, олігофренія, затримки в розумовому розвитку та інше) унеможливлюють нормальний процес навчально-пізнавальної діяльності і зумовлюють необхідність у спеціальній або інклюзивній освіті.

Сучасний суспільний устрій засуджує ізоляцію людей з різноманітними психофізичними особливостями та забезпечує право на повне інтегрування в суспільство різних верств населення і насамперед осіб з обмеженими можливостями. Одним з перших ступенів інтеграції людей з особливими потребами є рівний доступ до здобуття якісної освіти [1, с. 5].

Зокрема, найоптимальнішим видом освіти дітей з особливими потребами на сучасному етапі розвитку суспільства є інклюзивна освіта.

Одним із основних принципів інклюзивної освіти є принцип доступності, який ґрунтується на засадах дотримання прав людини та описано в резолюції Генеральної асамблеї ООН від 12 грудня 1997 року. Цей принцип спрямований на перенесення акцентів з медичних аспектів інвалідності , піклування про осіб з психофізичними порушеннями, захисту та надання їм допомоги в адаптації до навколишнього середовища на реформування самого соціуму, де особа з психофізичними порушеннями має змогу задовольнити свої потреби. Якісна освіта передбачає задоволення особливих освітніх потреб кожного індивіда, в тому числі і з порушеннями психофізичного розвитку, без відриву від звичного соціального оточення, сім'ї, друзів [1, с. 5].

Принцип доступності, який $є$ основним в інклюзивній освіті $€$ одним із найважливіших в концепції нової української школи, яка розглядає інклюзивну освіту як філософрію освіти. Нова українська школа характеризує інклюзивне навчання як систему освітніх послуг, гарантованих державою, що базується на принципі недискримінації, врахуванні багатоманітностей людини, ефективному залученні та включенні до освітнього процесу всіх його учасників. Для ефрективного здійснення інклюзивного навчання необхідно в першу чергу створити інклюзивне освітнє середовище. Нова українська школа визначає інклюзивне освітнє середовище як сукупність умов, способів і засобів іх реалізації для спільного навчання, виховання та розвитку здобувачів освіти 3 урахуванням їх потреб та можливостей [3].

Суспільно-соціальна концепція інклюзії стала основоположною в сучасній моделі здобуття освіти дітьми з особливостями психофрізичного розвитку інклюзивній освіті [1, с. 10].

Лише інклюзивна освіта, на думку одного з провідних нідерландських дослідників К. Рейсвейка, сприятиме розвитку здібностей дитини, визнанню 
того, що нормальний розвиток не $є$ загальноприйнятою "нормою", задоволенню особливих потреб, створенню системи підтримки, функціональному підходу до лікування та навчання, участі батьків у лікуванні та навчанні їхніх дітей [1, с. 10].

На основі наукової літератури А. Колупаєва визначає основоположні складові інклюзивної освіти, які зображено нами схематично (рис. 1.2).

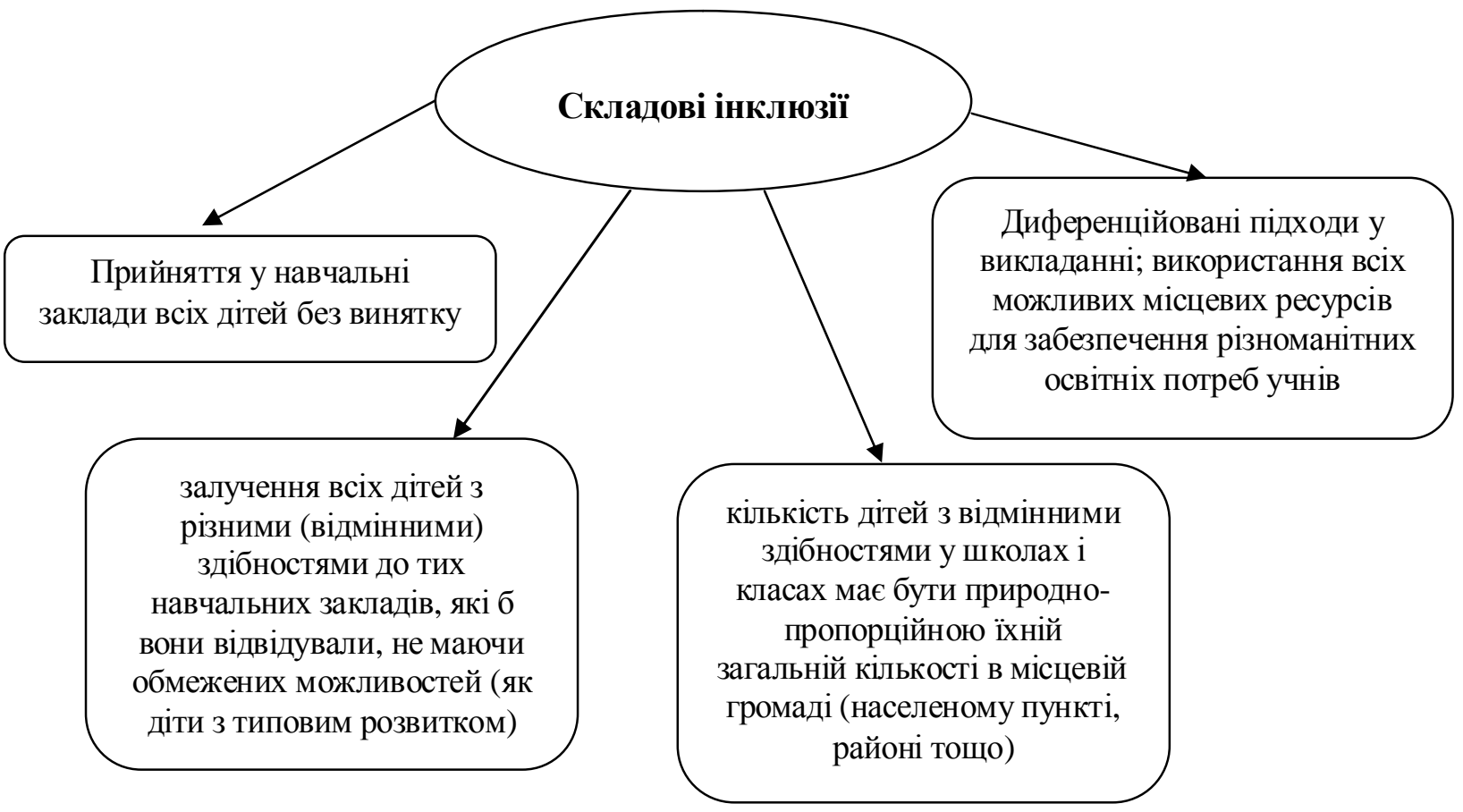

Рис. 1.2. Складові інклюзії. [1, с. 39]

Обговорюючи шляхи впровадження інклюзивної практики, освітяни зазвичай посилаються на низку проблем та перешкод. Серед них часто називають такі:

- відсутність належної підготовки педагогічних кадрів;

- неспроможність викладати відповідний навчальний матеріал дітям 3 різними здібностями (зокрема з особливостями психофізичного розвитку);

- брак ресурсів, щоб їм допомогти;

· усталені схеми фрунціонування школи та організації уроку [1, с. 39].

Учитель загальноосвітньої школи повинен бути готовим не тільки до професійно-педагогічної діяльності зі звичайними учнями, але й до корекційнопедагогічної роботи з дітьми, що мають психофрізичні особливості. Педагог як суб'єкт педагогічної діяльності повинен також уміти керувати розвитком, навчанням і вихованням учня, своєчасно і результативно проводити корекцію педагогічного впливу на особистість дитини, його поведінку і відношення до навчального середовища [5].

Організація діяльності вчителя початкових класів має полягати у цілеспрямованому розвитку вторинного порушення пізнавальної діяльності учня. Якщо у класі присутня дитина зі слабким слухом, слід активно використовувати залишковий слух у взаємозв'язку з розвитком навички 
читання 3 губ. Найкращими методичними прийомами для цього $\epsilon$ використання дидактичних ігор, інсценування, драматизація, пантоміма. Якщо присутній учень з порушенням зору, то діяльність вчителя змінюється згідно зі стадією цього порушення. Відповідно, чим гірше дитина бачить, тим більше вчитель повинен використовувати засоби і прийоми для сприймання явищ і предметів з опорою на слух, дотик, нюх. Наприклад під час проведення уроку математики в першому класі ефективним буде використання паличок Кюїзенера, за допомогою якого можна пояснювати склад числа, або здійснювати арифметичні дії.

До найважливіших корекційних умінь учителя, в класі якого $є$ діти 3 особливостями психофізичного розвитку, належать такі:

- бачити відхилення в розвитку дитини;

- проводити педагогічну діагностику разом з дефектологом і психологом;

- прогнозувати шляхи подальшого розвитку дитини 3 урахуванням наявного дефекту;

- попереджати причини виникнення порушень розвитку вторинних відхилень;

- визначати загальні і конкретні завдання корекційного навчання i виховання;

- планувати окремі види корекційної роботи;

- враховувати в навчально-виховному процесі характерні для дітей 3 особливостями психофрізичного розвитку можливості і фрактори компенсації, використовувати їх в корекційній діяльності;

- відбирати і застосовувати необхідні для вирішення корекційних завдань методи, прийоми і засоби навчання, виховання, діагностики, корекції, компенсації;

- створювати корекційні умови виховання, навчання, розвитку і соціальної адаптації дітей з особливостями психофізичного розвитку для засвоєння ними інтелектуального і морального досвіду в поєднанні 3 засвоєнням мови і мовлення;

- формувати позитивну мотивацію участі в корекційній роботі у дітей з особливостями розвитку і виховувати в них оптимізм, бачення життєвої перспективи, відчуття успіху;

- визначати результативність корекційної роботи на всіх етапах педагогічної діяльності;

- свідомо і критично управляти своєю корекційною діяльністю;

- працювати в тісному контакті з фахівцями: дефектологом, психологом, логопедом, медичними працівниками, а також з батьками [5].

У процесі підготовки майбутніх вчителів початкової школи, під час вивчення методик навчання початкової освіти, студенти освоюють спеціальні вправи, які необхідні для здійснення колекційної роботи, а також вправи на:

- зміцнення м'язів кисті руки, дрібної моторики пальців рук;

- розвиток орієнтування в просторі;

- розвиток пам'яті;

- розвиток уваги; 
- розвиток мислення;

- розвиток мовлення.

Наведемо кілька прикладів вправ для розвитку моторики і уваги:

1. Вправа "Повтори за мною".

Дитина повинна по інструкції:

а) протягнути руки вгору, вниз, направо, наліво (якщо не знає "направо", "наліво", то "на вікно", "на двері”); т.д.);

б) показати витягнутою рукою на названий предмет (вікно, стіл, книга і

в) намалювати крейдою (олівцем) круг (паличку, хрестик) вгорі, внизу, праворуч, ліворуч дошки (зошита).

2. Вправа "Який я сильний".

Вправа для пальців рук: розчепірити пальці, стиснути кулак - розтиснути; з стиснутого кулака по черзі випрямляти пальці.

3. Скачувати з пластиліну кульки, змійки, ланцюжки.

4. Вправа “Допоможи”.

Перекладати дрібні предмети (кульки) із однієї коробки в іншу. Зібрати розсипані на підлозі дрібні предмети в коробку [2].

Ці та інші вправи можна застосовувати під час роботи з дітьми, які мають особливі потреби. Наприклад на практичних заняттях з дидактики чи методик навчання різних освітніх галузей початкової освіти ми пропонуємо створювати фррагменти та конспекти уроків враховуючи відхилення у розвитку учнів інклюзивних класів.

Урок з математики в 4 класі (інклюзивний клас, в якому навчається дитина з вадами слуху).

Актуалізація опорних знань.

1. Математичний диктант (усний рахунок):

- Діти ви повинні усно порахувати значення виразів, написати великими цифрами відповідь на картках, які $є$ у кожного на парті і показати мені.

- Зменшуване 300, від’ємник 7. Знайди різницю (293);

- Перший доданок 120, другий 330. Зайди суму (450)

- Число 940 зменшити на 500. (440)

- Число 790 збільшити на 10. (800)

2. Гра "Правильно - неправильно"

Приготуйте сигнальні картки. Зараз я покажу вам три приклади в стовпчик 3 відповідями, але не у всіх буде написана правильна відповідь. Якщо результат правильний, потрібно показати зелену сигнальну картку, а якщо відповідь неправильна - червону.

$$
\begin{aligned}
& \overline{329} \overline{670} \overline{243} \\
& +483-435+531 \\
& \begin{array}{lll}
712 & 235 & 785
\end{array}
\end{aligned}
$$

Актуалізація опорних знань (інклюзія)

1. Картка з виразами.

$35+10=$

$100+30=$

$14+20=$

$200-100=$

2. Гра "Правильнонеправильно"

Асистент дає учню сигнальні картки і картку 3 завданням а прикладами. Учень перевіряе дані приклади і також сигналізує вчителеві

\begin{tabular}{cccc}
\cline { 1 - 1 }+429 & 670 & & 243 \\
+483 & -435 & & +531 \\
712 & 235 & 785
\end{tabular}


Таким чином, у процесі підготовки майбутнього вчителя початкової школи до забезпечення індивідуалізації інклюзивного навчання учнів початкової школи потрібно впроваджувати не лише теоретичну, але й практичну підготовку майбутніх фахівців (практичні заняття з методик навчання освітніх галузей початкової школи, педагогічну практику в спеціальних закладах освіти, інклюзивних класах). Під час підготовки конспектів занять з різних предметів обов'язково враховувати не тільки вікові особливості учнів, але й особливості, що пов'язані з особливими потребами, зумовленими різними вадами у психофізичному розвитку. Це вимагає створення особливих педагогічних умов для духовної, емоційної та інтелектуальної активності таких учнів, розвитку їх творчої активності, в процесі якої передбачається максимальний прояв індивідуальності. Відповідно до особливостей інклюзивної освіти для індивідуалізації навчання молодших школярів потрібно враховувати особливості сприймання, розумової активності, індивідуальних процесів функціонування психічної і пізнавальної діяльності учнів 3 особливими освітніми потребами.

\section{Використана література:}

1. Колупаєва А. А., Таранченко О. М., Білозерська І. О., Ленів 3. П. Основи інклюзивної освіти : навчально-методичний посібник. Київ, 2012. 308 с.

2. Корекційні вправи та ігри для дітей з особливими освітніми потребами / уклад. Орлова В. П. Кам'янське, 2018. 22 с.

3. Нова українська школа: порадник для вчителя / під заг. ред. Н. М. Бібік. Київ : ТОВ “Видавничий дім "Плеяди", 2017. 206 с.

4. Савчин М. В. Педагогічна психологія : навчальний посібник. Київ - Академвидав, 2007. 424 с.

5. Сєднєва В. О. Основи корекційної роботи з учнями, які мають особливості психофізичного розвитку : методичні рекомендації. Миколаїв : ОІППО, 2011. 36 с.

6. Тезаурус методичного працівника / уклад. і голов. ред. В. В. Демченко. Рівне: РОІППО, 2012. 72 с.

\section{References:}

[1] Kolupaieva A. A., Taranchenko O. M., Bilozerska I. O., Leniv Z. P. (2012) Osnovy inkliuzyvnoi osvity: navchalno-metodychnyi posibnyk. Kyiv. $308 \mathrm{~s}$.

[2] (2018) Korektsiyni vpravy ta ihry dlia ditei z osoblyvymy osvitnimy potrebamy / uklad. V. P. Orlova. Kamianske. $22 \mathrm{~s}$.

[3] (2017) Nova ukrainska shkola: poradnyk dlia vchytelia / pid zah. red. N. M. Bibik. Kyiv: TOV "Vydavnychyi dim "Pleiady". $206 \mathrm{s.}$

[4] Savchyn M. V. (2007) Pedahohichna psykholohiia : navchalnyi posibnyk. Kyiv - Akademvydav. 424 s.

[5] Siednieva V. O. (2011) Osnovy korektsiynoi roboty $\mathrm{z}$ uchniamy, yaki mayut osoblyvosti psykhofizychnoho rozvytku : metodychni rekomendatsii. Mykolaiv : OIPPO. $36 \mathrm{~s}$.

[6] (2012) Tezaurus metodychnoho pratsivnyka / uklad. i holov. red. V. V. Demchenko. Rivne : ROIPPO. $72 \mathrm{~s}$.

РАТУШНяк Н. О. Индивидуализация инклюзивного обучения учащихся начальной школь в системе подготовки будущих учителей.

В статье освещена проблема подготовки будущих учителей начальной школь $\kappa$ организаџии индивидуализации в инклюзивных классах. Проанализированы научные труды зарубежных и отечественных исследователей этой проблемы. Вылелены наиболее существенные признаки, характеризующие индивидуальный подход. Представлено структуру прочесса индивидуализаџии, в которой сформулировало процессуальные компоненть индивидуализачии и их элементы. Охарактеризованы основной принцип и составляющие 
инклюзивного образования. Определено наиболее важные функции учителя во время индивидуализации инклюзивного обучения: стимулирование познавательной деятельности; постоянный контроль за выполнением задач; подбор специальных методов; приемов и средств для учеников с особыми потребностями; своевременная помощь в преодолении трудностей в обучении. Выделены основные коррекционные умения, которыми должен обладать учитель инклюзивного класса начальной иколь. Предложено специальные упражнения для развития учашихся с особыми потребностями.

Ключевые слова: инклюзивное образование, ученики начальной школь, ученики с особыми потребностями, индивидуализачия обучения, индивидуальный подход, психофизические особенности, учебно-познавательная деятельность.

RATUSHNYAK NATALIA. Individualization of inclusive education of primary school students in the system of training future teachers.

The article highlights the problem of preparing future elementary school teachers to organize individualization in inclusive classes. The scientific works of foreign and domestic researchers of this problem are analyzed. The most significant features characterizing an individual approach are highlighted. The structure of the individualization process is presented, in which he formulated the procedural components of individualization and their elements. The basic principle and components of inclusive education are characterized. It was determined that the important functions of a teacher during the individualization of inclusive education are the stimulation of cognitive activity, constant monitoring of tasks, the selection of special methods, techniques and tools for students with special needs, timely assistance in overcoming difficulties in learning. The main correctional skills that a teacher of an inclusive class should have are highlighted. Special exercises are proposed for the development of students with special needs.

Keywords: inclusive education, elementary school students, students with special needs, individualization of education, individual approach, psychophysical features, educational and cognitive activity.

DOI: https://doi.org/10.31392/NZ-npu-145.2019.19

УДК 378. 155.9. 81

Резван О. О., Ільєнко О. Л.

\section{ПРОБЛЕМА ІМІДЖЕВОГО СПРИЙНЯТТЯ ПРОФЕСІЇ ФІЛОЛОГА У МІЖНАРОДНОМУ ДИСКУРСІ}

У статті доведено актуальність проблеми іміджевого підходу до професійної діяльності майбутніх перекладачів. Визначено компоненти персонального іміджу перекладача. Досліджено динаміку змісту компонентів поняття “імідж перекладача" у сучасних умовах ринку праці. Доведено вплив на імідж перекладача глобалізачійних прочесів світової економіки. Зауважено про важливість оперативного реагування на запити сучасного суспільства щодо послуг перекладача, зокрема для груп мігрантів. Визначено орієнтири іміджевого підходу підготовки майбутніх перекладачів у закладах вищої освіти.

Ключові слова: філолог, перекладач, імідж, глобалізачія, ринок прачі, професія, послуги. 